pag

Business School

WORKING PAPER SERIES

\begin{tabular}{c|l} 
Working Paper & $\begin{array}{l}\text { The Fiscal Implications of Hurricane } \\
\text { Strikes in the Caribbean }\end{array}$ \\
$2014-070$ & $\begin{array}{l}\text { Bazoumana Ouattara } \\
\text { Eric Strobl }\end{array}$
\end{tabular}

http://www.ipag.fr/fr/accueil/la-recherche/publications-WP.html

IPAG Business School

184, Boulevard Saint-Germain

75006 Paris

France

IPAG working papers are circulated for discussion and comments only. They have not been peer-reviewed and may not be reproduced without permission of the authors. 


\title{
The Fiscal Implications of Hurricane Strikes in the Caribbean
}

\author{
Bazoumana Ouattara \\ Swansea University \\ Eric Strobl ${ }^{1}$ \\ Ecole Polytechnique \& IPAG Research Lab
}

\begin{abstract}
We explore the fiscal impacts of hurricane strikes. To this end we derive a damage index from a physical wind field model, and assemble a panel data set of Caribbean countries over 36 years. Our results, based on panel var and impulse response frameworks, show that a typical strike significantly increases government expenditure in the year of the strike, with a smaller lagged effect in the subsequent year. Overall, the increase in expenditure has a negative impact on the budget balance in the year of the hurricane.
\end{abstract}

\footnotetext{
${ }^{1}$ Corresponding author. Address: Département d'Économie, Ecole Polytechnique, 91128 Palaiseau Cedex (France). Tel : +33 1693334 16. Fax: +33 1693334 27. Email: eric.strobl@polytechnique.edu.
} 


\section{Introduction}

Natural disasters are generally associated with considerable economic losses, often causing substantial and sustained disruption to normal economic activity. Particularly vulnerable in this regard are small countries, whose limited budgetary capacity prevents them from establishing sufficient financial reserves to such a relatively large negative shock. Additionally, the high debt level of most small economies limits their ability to access credit in the aftermath of a natural disaster, high transaction costs associated with the relatively small market limits access to private catastrophe insurance, and international assistance is often too little and comes too late. For example, when Hurricane Ivan struck the island of Grenada in 2004 causing over US $\$ 800$ million in damages, the country was no longer able to finance its public service bill and was forced to introduce a number of revenue enhancing measures and delay efforts of recovery and reconstruction in order to deal with the immediate problem of the fiscal shortfall, thus likely further amplifying the long term effects of the hurricane.

However, despite the arguable policy relevance of understanding the immediate fiscal impact of natural disasters, a review of the literature reveals that there are only a handful of studies that have addressed the issue, treating natural disasters as homogenous and using potentially measurement prone assessments of ex-post damages. ${ }^{2}$ In this paper we thus revisit the issue of the fiscal reaction to natural disaster events by studying the case of hurricane strikes in the Caribbean. To this end we construct a country level panel data set of various fiscal aspects and a hurricane destruction measure derived from actual hurricane tracks and physical wind field model. We then estimate the impact of hurricane strikes on the fiscal sector of Caribbean countries using impulse response functions.

\section{Hurricane Destruction Index}

\footnotetext{
${ }^{2}$ For example, Noy and Nualsri (2008) construct a country level panel data set and find that natural disaster events, measured by the monetary amount of direct damages, and find that while developed countries are characterized by a counter-cyclical fiscal reaction, developing countries respond via procyclical decreased spending and increasing revenues. Also, Lis and Nickel (2009), similarly in a cross-country panel data context, discover that the negative budgetary impact of extreme weather events can be up to 1.1 per cent of GDP, where the effect is generally larger for developing countries.
} 
The hurricane potential destruction index we use here is an ex-ante measure of potential destruction, rather than a potentially biased ex-post measure based on cost estimates. ${ }^{3}$ More specifically, our index is based on the physical characteristics of a hurricane, in particular on the fact that damages at any location are intrinsically linked to wind speed experienced. To estimate these local wind speeds we rely on the meteorological wind field model developed by Boose et al $(2004)^{4}$, which provides estimates of wind field velocity at any point $P$ relative to the 'eye' of the hurricane:

$V=G F\left[V_{m}-S(1-\sin (T)) \frac{V_{h}}{2}\right]\left[\left(\frac{R_{m}}{R}\right)^{B} \exp \left(1-\left[\frac{R_{m}}{R}\right]^{B}\right)\right]^{\frac{1}{2}}$

where $V_{m}$ is the maximum sustained wind velocity anywhere in the hurricane, $T$ is the clockwise angle between the forward path of the hurricane and a radial line from the hurricane center to the point of interest, $P, V_{h}$ is the forward velocity of the hurricane, $R m$ is the radius of maximum winds, $R$ is the radial distance from the center of the hurricane to point $P$, and $G$ is the gust wind factor. The relationship between these parameters and $P$ are depicted in Figure 2 . The remaining ingredients, $F, S$, and $B$, are scaling parameters for surface friction, asymmetry due to the forward motion of the storm, and the shape of the wind profile curve and are assumed to have values as in Boose et al (2004). ${ }^{5}$

Taken as a given that the power dissipation, and hence subsequent damage, of a hurricane is intrinsically related to its wind speed, then total potential destruction, WIND, due to a storm $r$ over its life time $\tau$ in any country $i$ at time $t$ is: ${ }^{6}$

$W I N D_{i, r, t}=\left(\sum_{j=1}^{J} \int_{0}^{\tau} V_{j t}^{\lambda} w_{i, j, r, t} d r\right) \quad$ if $V_{j t}>177 \mathrm{~km} / \mathrm{hr}(\mathrm{SS} \geq 3)$ and zero otherwise

\footnotetext{
${ }^{3}$ See Strobl (2011) for a discussion on this issue.

${ }^{4}$ This wind field model was, for instance, verified by the authors on data for Puerto Rico.

${ }^{5} F 1.0$ (water) and 0.8 (land); $G: 1.2$ (water) 1.5 (land); $S: 1.0 ; B: 1.3 ; R m: 50$.

${ }^{6}$ In essence this is a modified version of Emanuel's (2005) proposed destruction index.
} 
where $\mathrm{V}$ are estimates of local wind speed at localities $j, J$ is the set of localities $j$ within country $i, w$ are weights assigned according to characteristics of the locality to capture the 'potential' damage there, and $\lambda$ is a parameter that relates local wind speed to the local level of damage.

In terms of the weights $w$ we use the time varying share of population of each individual locality $j$ at $t-1$, where the underlying argument is that, even if severely damaged by hurricane winds, sparsely populated areas are unlikely to play a significant role in the overall macroeconomic impact of a hurricane for a country in any year. For these weights $w$ we resort to the Latin America and Caribbean Population Database (LACPD), which provides data on the spatial distribution of the region for 2.5 minute grid cells for 1960, 1970, 1980, 1990, and 2000. We use this spatial breakdown as the set of our points $J$. In order to derive annual national population share figures for each grid cell for each country in our analysis, we used an intercensal growth rate to interpolate data for years between the given values.An important input variable to $(2)$ is $\lambda$, i.e., the parameter that links wind speed to its level of destruction. In this regard Emanuel (2005) noted that both the monetary losses as well as the power dissipation of hurricanes tend to increase as the cube of the maximum observed wind speed rises, and hence argues that the destructiveness of a hurricane can roughly be measured by the cubic value of its maximum observed wind speed. We thus similarly assume the value of $\lambda$ to be 3 . One may also want to note that in (2) we focus only on wind speeds that cause significant damages, i.e., on those that that are of least strength 3 on the SS scale, as discussed in Strobl (2011).

For information on hurricanes in the Caribbean region we rely on the North Atlantic Hurricane database (HURDAT) and the Eastern North Pacific Tracks File, maintained by the National Hurricane Center, which consist of six-hourly positions and corresponding intensity estimates in terms of maximum wind speed of tropical cyclones in the North Atlantic Basin over can be considered essentially account of tropical storm activity in the region. ${ }^{7}$ We linearly interpolated the positions and wind speeds between the six hourly data to obtain three hourly track data since hurricanes can move considerable distance in just a few hours. Given the sample period of our economic data (which starts earliest for some countries in 1970), we limit

\footnotetext{
${ }^{7}$ For a detailed description see Elsner (2003) and Jagger and Elsner (2004).
} 
our use of these data to the period from 1970 onward. In Figure 1 (see Appendix) we depict the tracts of all tropical storms from the HURDAT database that are relevant to the period of our analysis, i.e., from 1970-2006, where the parts of the tracts are when the storms reached wind speeds of at least SS Scale of 3. Noteworthy is that there are a large number of tropical storms that travel through the Caribbean region, but only a few translate into major storms and come close enough to land to be potentially damaging.

In terms of applying our wind field model to obtain local wind intensity estimates, we followed each tropical cyclone over each point of the interpolated track and calculated the wind intensity experienced by each grid cell as long as these fell within $500 \mathrm{~km}$ of the hurricane eye's location ${ }^{8}$, providing us with a complete set of estimates of wind speeds experienced by all spatially relevant localities relative to each position of each tropical cyclone. Using the estimates above we then calculated local destruction at localities $j$ as given by (2) before aggregating them to the country level.

Our data for fiscal variables comes from the World Development indicators (2003 and online version) and includes information on government consumption (includes all government current expenditures for purchases of goods and services); tax revenue ( which includes compulsory transfers to the central government for public purposes); public investment (outlays by the public sector) ${ }^{9}$, and debt stock (total external debt). All our fiscal variables are expressed in percentage of GDP. All in all the not fully complete fiscal variables data reduces our sample of study to an unbalanced panel of 18 Caribbean countries over the 1970-2006 period. ${ }^{10}$

\footnotetext{
${ }^{8}$ Hurricanes have been observed to reach up to a maximum of size of $1000 \mathrm{~km}$ in diameter.

${ }^{9}$ We use gross fixed capital formation for this purpose

${ }^{10}$ The countries included are Cayman Islands, St. Kitts\&Nevis, Antigua, Jamaica, Bahamas, Dominica, Dominican Republic, St. Lucia, Barbados, Haiti, Aruba, St.Vincent\&Grenadines, Grenada, Netherlands Antilles, Honduras, Trinidad\&Tobago, Surinam, Guyana.
} 


\section{Econometric Analysis}

\section{Methodology}

To capture the impact of hurricane strikes on our fiscal variable we employ Impulse Response Function (IFR) analysis. The IFRs are generally derived from a (panel) vector autoregression (PVAR) framework. The PVAR model, in its reduced form, can be represented by:

$$
Z_{i t}=B(L) Z_{i t-1}+u_{i t}
$$

Where $Z_{i t}$ is an $m \times 1$ vector of endogenous variables, $B(L)$ is a matrix polynomial in lag operator $L, m$ is the number of variables in the model, and $u_{i t}$ is the reduced-form residual vector. Using the estimates of the above model one can obtain the structural-form model as:

$$
A_{0} Z_{i t}=A(L) Z_{i t-1}+w_{i t}
$$

Where $A_{0}$ is the $m \times m$ contemporaneous structural parameter matrix with 1 's on the diagonal; $A(L)$ is a matrix polynomial in the lag operator $L$, and $w_{i t}$ is the structural disturbance vector which contains the orthogonal structural shock to each equation of the VAR. ${ }^{11} w_{i t}$ is assumed to have zero mean and a variance-covariance matrix: $w_{t} w_{t}{ }^{\prime}=\Sigma \mathrm{u}$. The problem in the VAR literature is the issue of identification. The question is how to translate $w_{\mathrm{t}}$ to economically meaningful or fundamental shocks, $\theta_{\mathrm{t}}$. Given that there are potentially $\mathrm{m}$ fundamental shocks, identification of these shocks amount to identifying a matrix $D$ such that $w_{t}=\mathrm{D} \theta_{\mathrm{t}}$ and $D D^{\prime}=\Sigma w$. In this paper, we are not dealing with the shock of our fiscal variables on our hurricane index, hence we are not dealing with all the $\mathrm{m}$ potential shocks. One may also want to note that in all our IFRs we control for country fixed effects by forward mean differencing variables, as well as include year specific effects to eliminate any cross-country

\footnotetext{
${ }^{11}$ By pre-multiplying the structural-form VAR equation by $A_{0}^{-1}$ we obtain its reduced-form.
} 
contemporaneous residual correlation.

\section{Results}

We present, in Table 1, the contemporaneous and lagged effect of hurricanes on our five different fiscal variables as estimated from the IFRs along with their $95 \%$ confidence interval, as well as their graphical depiction in Figure $2 .{ }^{12}$ As can be seen, a hurricane strike of Saffir Simpson Scale 3 results in an immediate incrase in government spending. As a matter of fact, the point estimate suggests that the average hurricane strike increases government spending (as a share of GDP) by 4.1 percentage points. There is also positive effect in the year folowing the strike, albeit only about a third of the contemporaneous one, after which the data suggests no further significant increase in public expenditures. The increase in government consumption could be explained by the cost of the environment cleanup following the disaster (e.g., wages paid to overtime workers and short term contractual workers), as well as governments paying to provide shelter and other support for those who are unemployed, injured, or seriously affected. In contrast, if we look at the direct spending on infrastructure there appears to be no measured effect from our IFR analysis (Figure 2). Possible explanations may be that infrastructure remains relatively undamaged and/or that its repair and replacement is primarely financed by the private and foreign sectors.

Looking at the public revenue side of fiscal policy our IFRs also suggest no discernable impact from a hurricane strike. Neverthless, the increase in goverment expenditure does, unsurprisingly, results in an overall fall in the budget balance in the year of a Saffir Simpson Scale 3 hurricane, roughly around 0.9 percentage points (of GDP). In contrast, the smaller impact on public expenditures in the subsequent year does not on average translate into a reduced budget. Examining the long term effect of the resultant balanced budget, one sees that there appears to be no impact on overall debt.

\footnotetext{
${ }^{12}$ Based on the AIC we used a lag order 2. One should also note that panel unit root tests indicated that all our variables were stationary.
} 
Table 1: Fiscal response to hurricane Saffir Simpson Scale 3 shocks

\begin{tabular}{|l|c|c|c|c|c|}
\hline \multicolumn{1}{|c|}{$\begin{array}{c}\text { Fiscal } \\
\text { variables }\end{array}$} & $\begin{array}{c}\text { Instantaneous } \\
\text { response }\end{array}$ & $\begin{array}{c}\text { Response after } \\
1 \text { year }\end{array}$ & $\begin{array}{c}\text { Response after 2 } \\
\text { years }\end{array}$ & $\begin{array}{c}\text { Response } \\
\text { after 3years }\end{array}$ & $\begin{array}{c}\text { Response } \\
\text { after 5 years }\end{array}$ \\
\hline $\begin{array}{l}\text { Government } \\
\text { spending }\end{array}$ & $\begin{array}{c}1.149 \\
{[3.3625 .201]}\end{array}$ & $\begin{array}{c}1.432 \\
{[0.0682 .931]}\end{array}$ & $\begin{array}{c}0.721 \\
{[-0.9442 .504]}\end{array}$ & $\begin{array}{c}0.697 \\
{[-0.8592 .337]}\end{array}$ & $\begin{array}{c}0.672 \\
{[-0.6552 .347]}\end{array}$ \\
\hline $\begin{array}{l}\text { Public } \\
\text { investment }\end{array}$ & 0.266 & -0.225 & 0.826 & 0.977 & 0.736 \\
{$[-0.7281 .336]$} & {$[-1.5091 .058]$} & {$[-0.7682 .500]$} & {$[-0.6612 .661]$} & {$[-0.8262 .452]$} \\
\hline Debt & 2.592 & 4.949 & 11.440 & 14.125 & 15.311 \\
& {$[-4.3349 .794]$} & {$[-6.139$} & {$[-2.42626 .552]$} & {$[-2.630$} & {$[-2.273$} \\
& & $16.737]$ & & $32.705]$ & $37.027]$ \\
\hline Tax & 0.801 & -0.262 & -0.196 & 0.278 & 0.209 \\
& {$[-0.6732 .324]$} & {$[-2.2221 .704]$} & {$[-2.4182 .016]$} & {$[-1.8692 .495]$} & {$[-1.4902 .205]$} \\
\hline Budget balance & -0.856 & -0.327 & -0.268 & -0.040 & 0.015 \\
& {$[-1.430-0.355]$} & {$[-1.0050 .310]$} & {$[-1.0620 .495]$} & {$[-0.611$} & {$[-0.4390 .471]$} \\
& & & & $0.532]$ & \\
\hline
\end{tabular}

Notes: (a) 5 and 95 percent confidence band in brackets [ ]. (b) Error bands obtained via Monte Carlo simulations (1000 replications). (c) Budget balance is constructed out of its component.

Figure 2: Impulse response functions
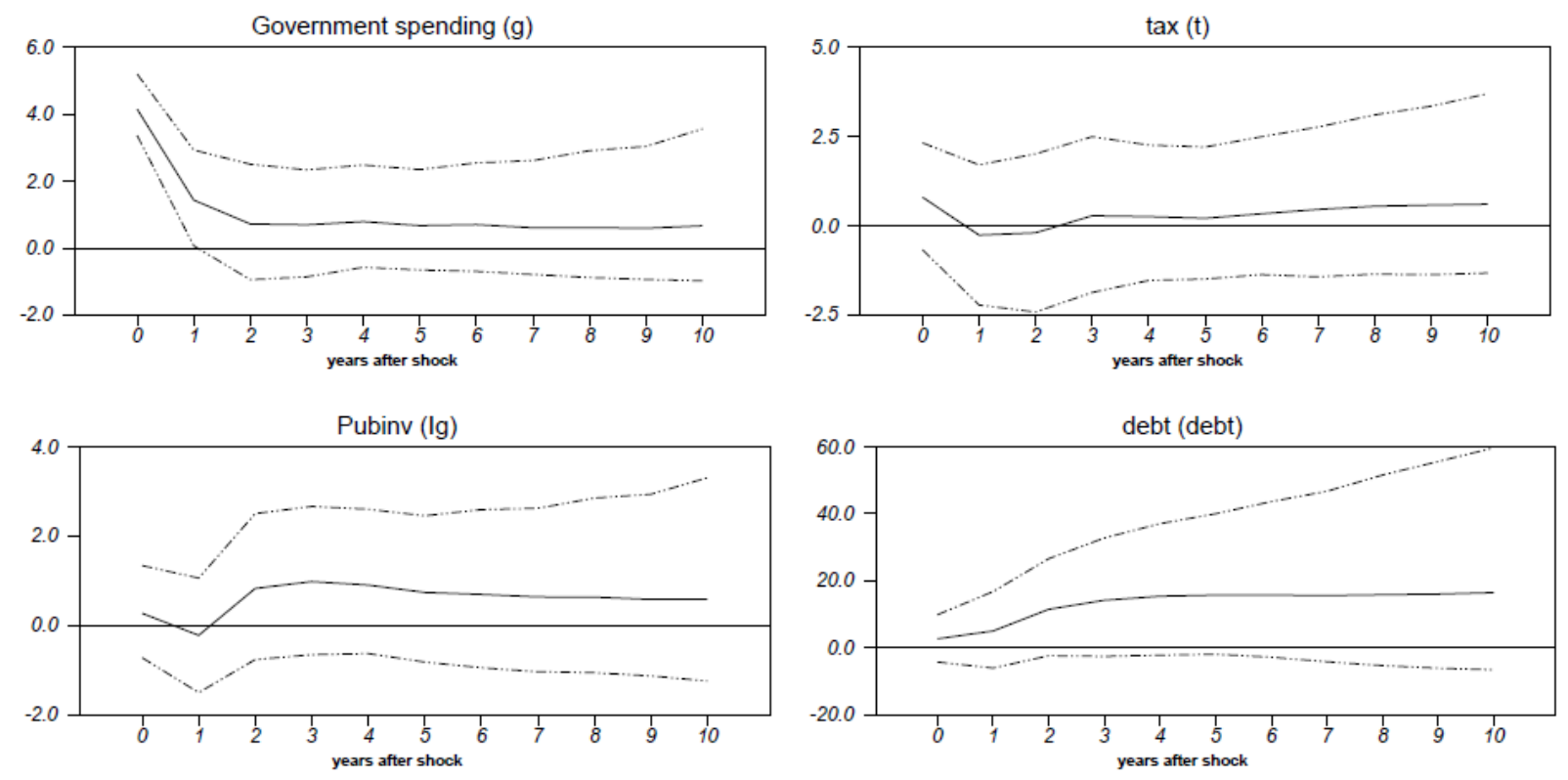


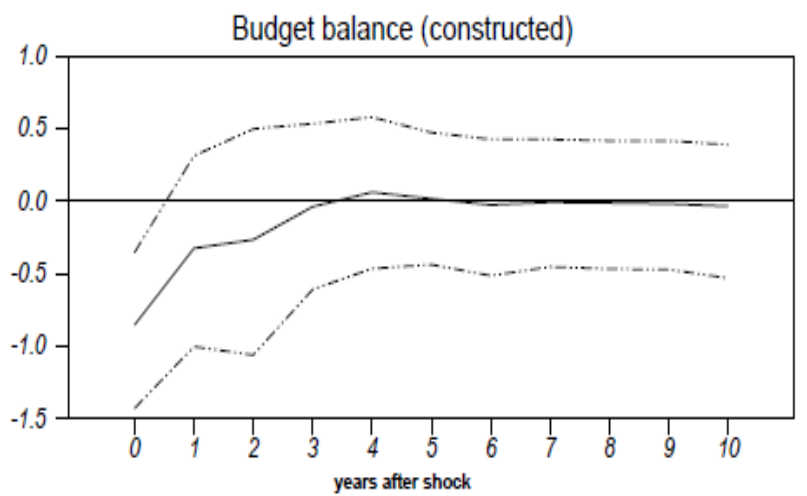

\section{Conclusion}

We explored the response of various aspects of fiscal policy to hurricane shocks for 18 Caribbean countries over the 1970-2006 period. For this purpose we constructed a hurricane potential destruction index based on actual hurricane track data and used a panel VAR and impulse response framework. Our results indicate that governments respond to hurricane strikes by immediately increasing government consumption in the year of the shock, but that this increase quicly dies out within two years of the strike. In contrast, we find no paralell fall in government revenues. Overall this results in a fall in the government budget for the year of the strike, but with no discernable effect on government debt.

\section{References}

Boose, E., Serrano, M. and Foster, D. (2004) "Landscape and Regional Impacts of Hurricanes in Puerto Rico", Ecological Monograph, 74, pp. 335-352.

Emanuel, K. (2005). "Increasing Destructiveness of Tropical Cyclones over the past 30 Years", Nature, 4th August 2005, pp. 686-688. 
Elsner, J. (2003). "Tracking Hurricanes", Bulletin of the American Meteorological Society, 84, pp. 353-356.

Holland, G. (1980). "An Analytic Model of the Wind and Pressure Profiles in Hurricanes", Monthly Weather Review, 106, pp. 1212-1218.

Jagger, T., and Elsner, J. (2004). "A Hierarchial Baysian Approach to Seasonal Hurricane Modeling", Journal of Climate, 17, pp. 2813-2827.

Jagger, T., and Elsner, J. (2006). "Climatology Models for Extreme Hurricane Winds near the United States", Journal of Climate, 19, pp. 3220-3236.

Lis, E. and Nickel, C. (2009). "The Impact of Extreme Weather Events on Budget Balances and Implications for Fiscal Policy", European Central Bank Working Paper Series, 1055, May 2009.

McGranahan, G., Balk, D., and Anderson, B. (2007). "The Rising Tide: Assessing the Risks of Climate Change and Human Settlements in Low Elevation Coastal Zones", Environment and Urbanization, 19, pp. 17-37.

Nordhaus, W. (2006). "The Economics of Hurricanes in the United States", NBER Working Paper No. W12813.

Noy, I. and Nualsri, A. (2008). "Fiscal Storms: Public Spending and Revenues in the Aftermath of Natural Disasters", mimeo, available at: www.sciie.ucsc.edu/workingpaper/2008/IlanNoy fiscal-disasters \%2012.06.pdf

Pielke, R., Gratz, J., Landsea, C., Collings, D. (2008). "Normalized Hurricane Damages in the United States: 1900-2005", Natural Hazards Review, 29, pp. 29-42.

Rappaport, J. and Sachs, J. (2003). "The United States as Coastal Nation", Journal of Economic Growth, Vol. 8. pp. 5-46.

Southern, R. (1979). "The Global Socio-Economic Impact of Tropical Cyclines", Australian Meteorological Magazine, 27, pp. 175-195.

Strobl, E. (2010). "The Economic Growth Impact of Hurricane Strikes: Evidence from US Coastal Counties", Review of Economics and Statistics, forthcoming.

Strobl, E. (2011)."The Economic Growth Impact of Natural Disasters in Developing Countries: Evidence from the Central American and Caribbean Region", Journal of Development Economics, Forthcoming.

World Bank (2008). "Caribbean Catastrophe Risk Insurance Facility", in Financing Relief and Development. 
Yang, D. (2007). "Coping with Disaster: The Impact of Hurricanes on International Financial Flows, 1970-2002", Advances in Economic Analysis \& Policy (B.E. Press), 8, Article 13. 
Figure 1: Tropical Storms in the Caribbean Region 1970-2005

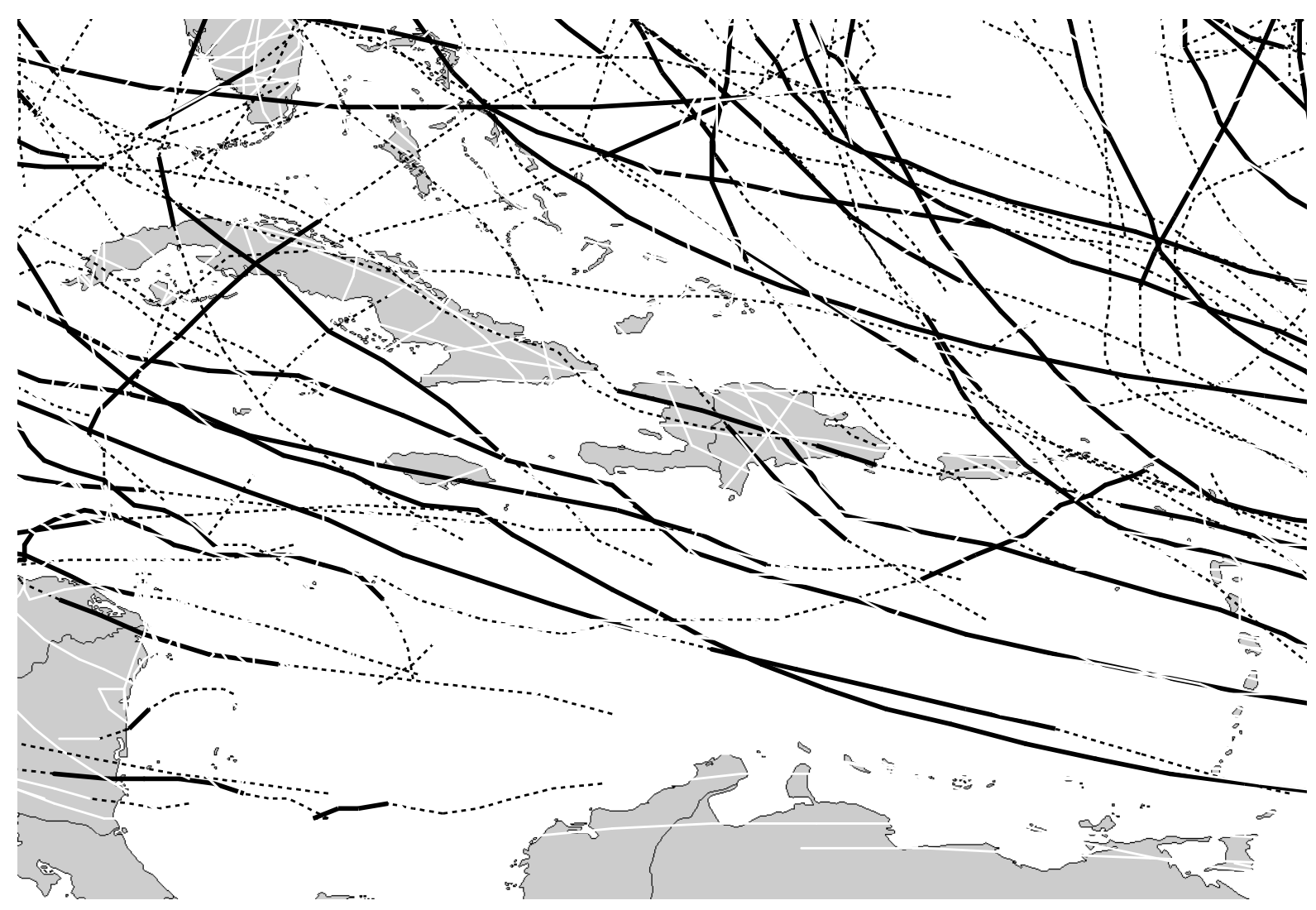

Notes: Dark lines indicate when storms reached at least SS Scale of 3 levels. 